\title{
MANIFESTĂRI CLINICE ÎN PERIOADELE DE APLAZIE SECUNDARĂ CHIMIOTERAPIEI
}

\author{
Asist. Univ. Dr. Erzsébet Papp Zsuzsanna, Conf. Dr. Mária-Adriene Horváth \\ Secția Clinică Pediatrie, Spitalul Clinic Județean Mureş, \\ Universitatea de Medicină şi Farmacie, Târgu-Mureş
}

\begin{abstract}
REZUMAT
Obiectiv. Evidențierea semnelor şi simptomelor clinice ale aplaziilor medulare secundare chimioterapiei anticanceroase de atac.

Material şi metodă. Lotul de studiu cuprinde 20 copii (9 luni-18 ani) spitalizați în compartimentul hematooncologie pediatrică al Spitalului Clinic Județean Mureş - secția clinică de Pediatrie, cu următoarele diagnostice: Leucemia acută limfoblastică - LAL, tumoră Wilms - WT, Leucemie acută mieloblastică - LAM, Limfom Hodgkin LH, Limfom cu celule mari anaplastice non-Hodgkin - LNH, tumoră cu celule mici rotunde desmoplazice - TD, Neuroblastom presacrat tratat şi recidivate - NB. Criteriul de includere în studiu a fost chimioterapia de atac, iar de excludere tratamentul citostatic de întreținere. S-a alcătuit un protocol de supraveghere clinico-biologică în dinamică, adresat cu precădere reflectării clinice a aplaziilor induse de fiecare bloc citostatic. Aplazia medulară a fost atestată de prezența neutropeniei, anemiei şi trombocitopeniei.

Rezultate şi discuții. În studiu s-au încadrat 20 copii (9 fete, 11 băieți) cu tratament intens citostatic. Patologia majoritară a fost LAL (60\%), apoi a urmat WT (3 cazuri) şi câte un caz de LAM, LH, LNH, TD, NB. Vârsta copiilor era cuprinsă între 9 luni şi 18 ani (VM-7.18), distribuția grupelor de vârstă respectând datele din literatura de specialitate. Toți pacienții au fost tratați conform protocoalelor internaționale. După fiecare bloc citostatic a urmat o perioadă de aplazie. Patologia aferentă a constat din anemii, trombocitopenii, mucozită, infecții cu diferite localizări, reactivare zona zoster secundară imunodeprimării.

Concluzii. Aplazia medulară postcitostatică a avut durată şi severitatea diferită în funcție de tipul de cancer Durata, severitatea complicațiilor clinice şi rezistența la tratament au fost severe în LAL şi leucemia mieloblastică. Complicațiile infecțioase au evoluat cu nuanțe individualizate generate probabil de particularitățile imunologice.
\end{abstract}

Cuvinte cheie: aplazie secundară, copil, chimioterapie, cancer

\author{
Abrevieri folosite: \\ Cefalosporină generația 2, 3 - CG2, 3 \\ Cromosom Philadelphia - cr.Ph \\ Cateter venos central - CVC \\ Factor de stimulare al coloniilor granulocitari - FSCG \\ Hemoragie digestivă inferioară - HDI \\ Hemoragie digestivă superioară - HDS \\ Nefroblastom (Tumora Wilms) - WT \\ Limfom Hodgkin - LH \\ Limfom non-Hodgkin - LNH \\ Leucemia acută limfoblastică - LAL \\ Leucemia acuta mieloblastică - LAM \\ Tumoră cu celule mici rotunde desmoplazice - TD
}

Neuroblastom - NB

\section{INTRODUCERE}

Cancerul la copil este o patologie extrem de rară, reprezentând doar $2 \%$ din patologia pediatrică şi aproximativ $2 \%$ din totalul bolilor canceroase. Anual apar 200.000 de cazuri de cancer pediatric, iar în România se depistează aproximativ 500 de cazuri. (1) Momentan 5.000 de copii sunt în evidenţă cu diagnostic de boală malignă aflați sub tratament intens citostatic sau fiind în remisie. (2)
Cancerele pediatrice prezintă un profil de incidenţă specific: leucemiile şi limfoamele pe primul loc, urmate de tumorile cerebrale - locul al doilea, după care urmează neuroblastomul, nefroblastomul (tumora Wilms), retinoblastomul, hepatoblastomul, rabdomiosarcomul. (3)

Arsenalul terapeutic variază în funcție de diagnostic şi constă în chimioterapie, rezolvare chirurgicală, radioterapie şi transplant de măduvă osoasă, iar tratamentul va fi ales întotdeauna pe baza

Adresa de corespondență:

Asist. Univ. Dr. Erzsébet Papp Zsuzsanna, Spitalul Clinic Județean Mureş, Str. Gheorghe Marinescu nr. 38, Târgu-Mureş

E-mail: pappzsuzsi@freemail.hu 
protocoalelor internaționale bine stabilite, dar şi personalizat. Supraviețuirea totală în oncologia pediatrică este descrisă în literatura de specialitate fiind în jur de $80 \%$, în unele patologii raportându-se chiar şi mai optimist (LAL, WT) (4), însă în continuare rămân anumite boli unde prognosticul a rămas în jurul valorii de 50\% (LAM, NB). (1)

Citostaticele vizează distrugerea celulelor canceroase însă dintre multiplele efecte secundare trebuie amintit perioada aplaziilor, când măduva osoasă nu produce precursorii celor 3 linii celulare importante - leucocite, eritrocite, trombocite. Din aceste lipsuri vor succeda multiplele complicații, cu semnele şi simptomele asociate care pot periclita viaţa pacienților.

\section{MATERIAL ŞI METODĂ}

Studiul nostru a decurs în perioada 2014 martie 2015 decembrie în cadrul compartimentului de hemato-oncologie pediatrică al Spitalului Clinic Județean Mureş, Secția Clinică de Pediatrie. Criteriul de includere a fost tratamentul intens citostatic pentru boală malignă, s-au exclus copiii internați în secție pentru tratament citostatic de întreținere. Am studiat perioadele de aplazie prin examinări clinice succesive pentru depistarea acuzelor subiective/ manifestărilor clinice şi analizele de laborator care vizau parametrii hematologici, biochimici.

\section{REZULTATE}

În studiu s-au încadrat 20 copii ( 9 fete, 11 băieți) cu tratament intens citostatic. Patologia majoritară a fost LAL cu celule preB (60\%), apoi a urmat WT (1 caz cu metastaze pulmonare) şi câte un caz de LAM cu celule M2, LH, LNH, Tu cu celule mici desmoplazice std. 4 cu metastaze hepatice, Neuroblastom presacrat tratat si recidivat. (Fig. 1) Vârsta copiilor era cuprinsă între 9 luni şi 18 ani (VM 7,18). (Fig. 2)

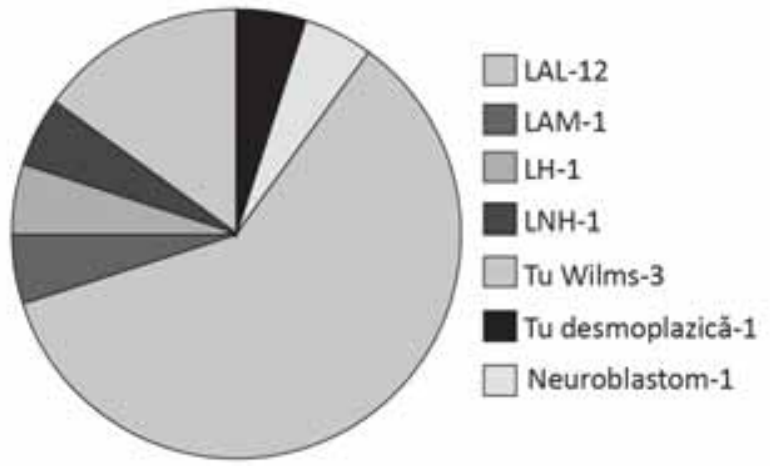

FIGURA 1. Distribuția patologiei

Toți pacienții au fost trataţi conform protocoalelor internaționale, astfel cei cu LAL cu ALL-BFM 2002 ( 1 caz de LAL cr.Ph+ asociat cu Imatinib) respectiv sugarul de 9 luni cu Interfant 99, AML cu AML-BFM 2002, LH cu HD-DAL 90, LNH cu ALCL international protocol 2000, WT cu SIOP Nefroblastoma 2000, NB cu protocol SIOPEN VP/ CARBO+ CADO, Tu Desmoplazica cu CWS 2009. Dintre pacienții cu LAL 4 au fost incluşi în risc înalt pe baza imunofenotipizării, a afectării SNC la debut, a prezenței cromosomului Philadelphia, respectiv a răspunsului la Prednison în Z8. Tumorile solide au fost diagnosticate în stadii avansate 3-4, ceea ce a îngreunat atitudinea terapeutică.

După fiecare bloc citostatic a urmat o perioadă de aplazie. Durata medie a perioadelor de aplazie la copii cu leucemie a fost semnificativ mai lungă 15,23 zile decât la cei cu tumori solide $-4,71$ zile ( $\mathrm{p}<0,0001)$ - Fig. 3 .

Valorile hematologice extreme găsite au variat între Hgb $5 \mathrm{~g} / \mathrm{dl}$ (LAL) şi $7 \mathrm{~g} / \mathrm{dl}$ (LNH), Leucocite 20/mmc (LAL) şi 450/mmc (NB), Trombocite 2.500/mmc (LAL) şi 20.000/mmc (NB) - Fig. 4.

La valorile scăzute ale $\mathrm{Hgb}$ nici un copil nu a semnalat acuze subiective, iar clinic s-a observat paloare tegumentară. Trombocitopenia a cauzat la 3 copii cu LAL incidente majore sângerânde (meno-

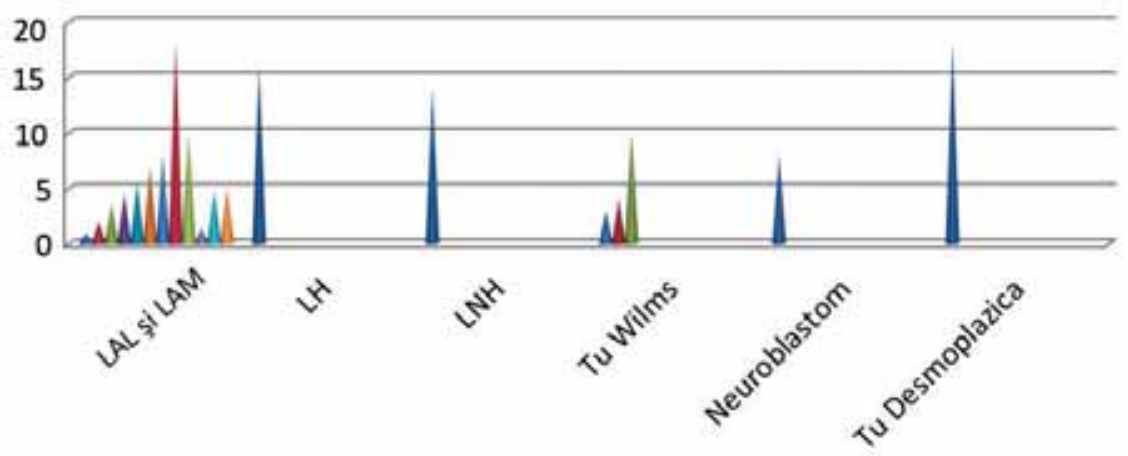

FIGURA 2. Distribuția patologiei pe grupe de vârstă 


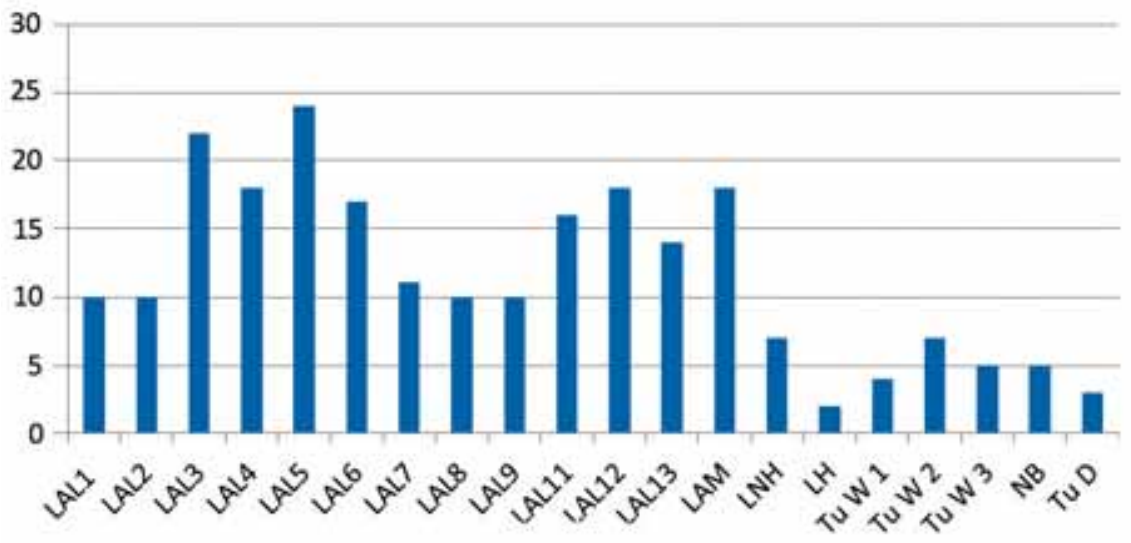

FIGURA 3. Durata medie a perioadelor de aplazie - diferență semnificativă între cei cu leucemii acute şi tumori solide + limfoame

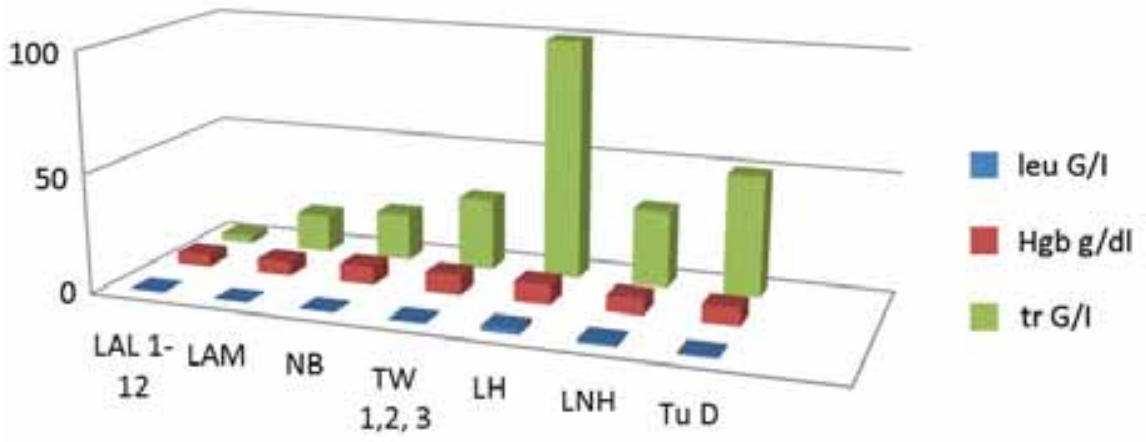

FIGURA 4. Parametrii hemtologici - valori extreme găsite

metroragie, HDI, epistaxis repetat) respectiv la 1 copil cu WT HDI. Manifestări purpurice şi echimoze s-au observat la 3 copii cu LAL.

Leucopenia s-a complicat prin infecții la toți copiii cu leucemie acută şi la cei cu tumori solide, în afara pacientului cu tumoră cu celule mici rotunde desmoplazice care nu a prezentat febră niciodată în perioadele de aplazie. (Fig. 5) Astfel, toți copiii cu leucemie (13) şi pacientul cu limfom nonHodgkin au prezentat, concomitent cu scăderea numărului leucocitelor, apariția leziunilor bucale (afte/vezicule) care s-au şi suprainfectat în timp, cauzând ulcerațiii. (Fig. 6, 7) Culturile luate din leziuni nu au ieşit pozitive. Acuzele subiective la toți erau durere intensă la masticație, refuzul alimentației.

Următoarea patologie ca şi frecvență a fost pneumonia bacteriană care s-a manifestat la 8 copii cu LAL, pacienta cu LAM, 2 dintre copii cu WT, la pacientul cu LNH şi la cea cu NB. Semnele clinice erau tuse, febră, dispnee. Tratamentele au constat din antibioterapie asociată (CG2-3, Meropenem, tratament antistafilococic) şi suport imunologic

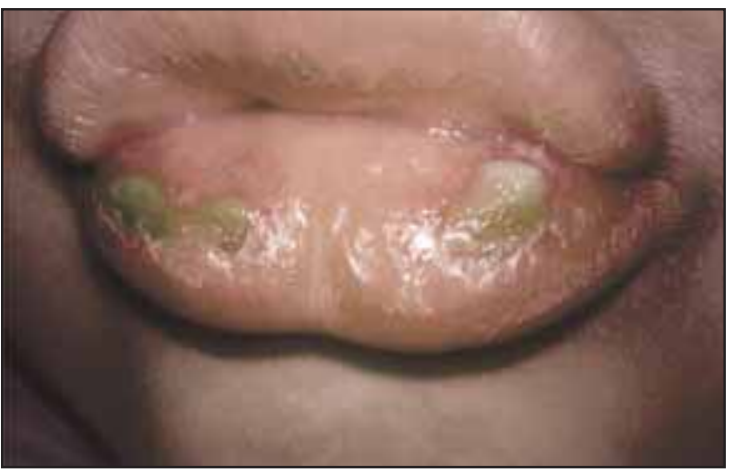

FIGURA 6, 7. Leziuni de mucozită la un pacient de 10 ani $\mathrm{Cu} L A L$ pre $B$ risc mediu

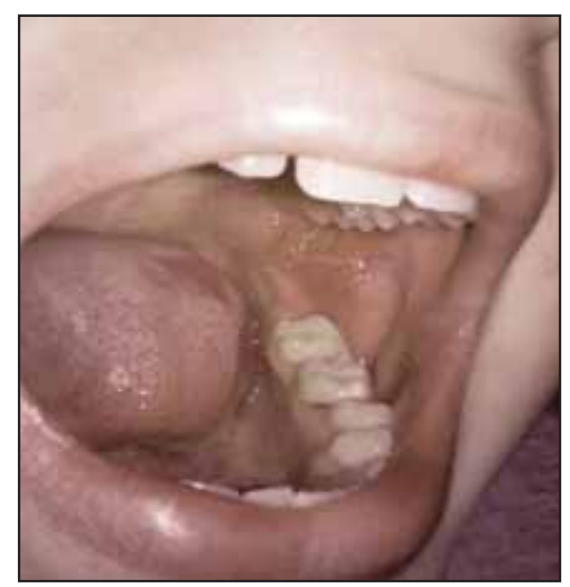


prin imunoglobuline intravenoase. La un pacient în vârstă de 12 ani cu LAL cu cr.Ph pozitiv după o cură citostatică agresivă (a 8-a luna de tratament) a apărut Aspergiloza pulmonară care în ciuda terapiei antifungice intravenoase asociate a decedat în a 5-a zi după apariția semnelor clinice (tuse seacă iritativă, subfebrilitate/febră, dispnee, hemoptizie).

Infecțiile enterale au apărut la 5 copii cu LAL şi pacienta cu LAM şi constau în dureri intense abdominale, dureri intense în regiunea perianală (la defecație şi în poziție şezândă), diaree apoasă cu sau fără elemente patologice în scaun, iar coproculturile nu au ieşit pozitive. Tratamentul antibiotic asociat de spectru larg administrat 2 săptămâni a rezolvat infecțiile la toți pacienții. După o cură citostatică efectuată în noiembrie 2015 fiind epidemie de Rotavirus la 3 pacienți am identificat virusul (11 luni, 1,5 ani şi 4,5 ani).

Dintre pacienții internați şi trataţi, 4 copii $\mathrm{cu}$ LAL au prezentat infecții cutanate: panariții (Fig. 8), abcese cutanate, intertrigo fesier suprainfectat (Fig. 9), infecție deasupra CVC prin sistem port (Fig. 10) şi la un pacient obez celulita țesutului gras în regiunea pectorală care a condus la pierderea CVC tunelizat. Durata medie de vindecare a fost de 11 zile.

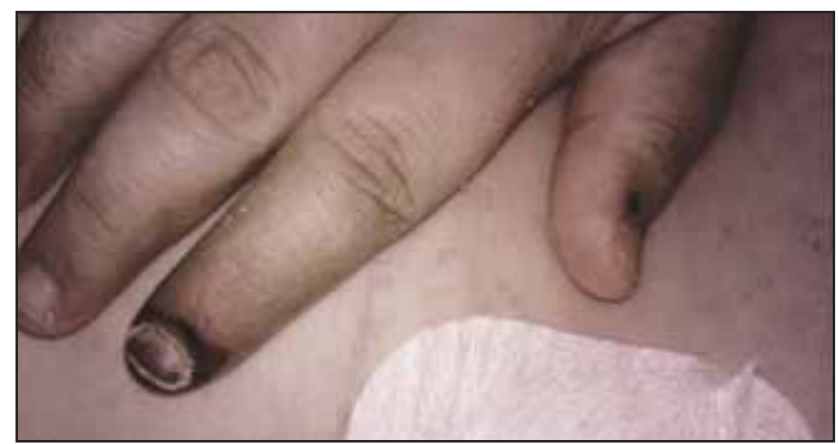

FIGURA 8. Panaritiu în curs de vindecare la o pacientă de 4,5 ani cu $L A L$ pre $B$ risc mediu

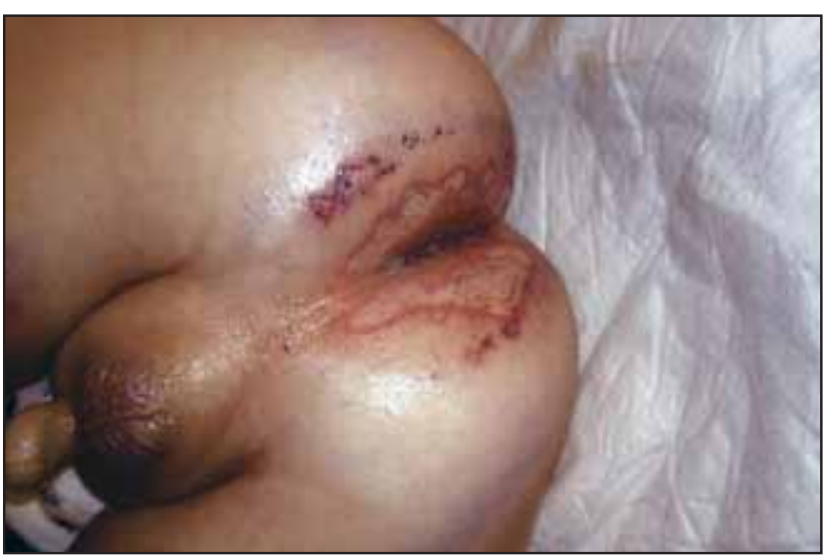

FIGURA 9. Intertrigo fesier suprainfectat la un pacient de 2 ani cu LAL preB risc mediu

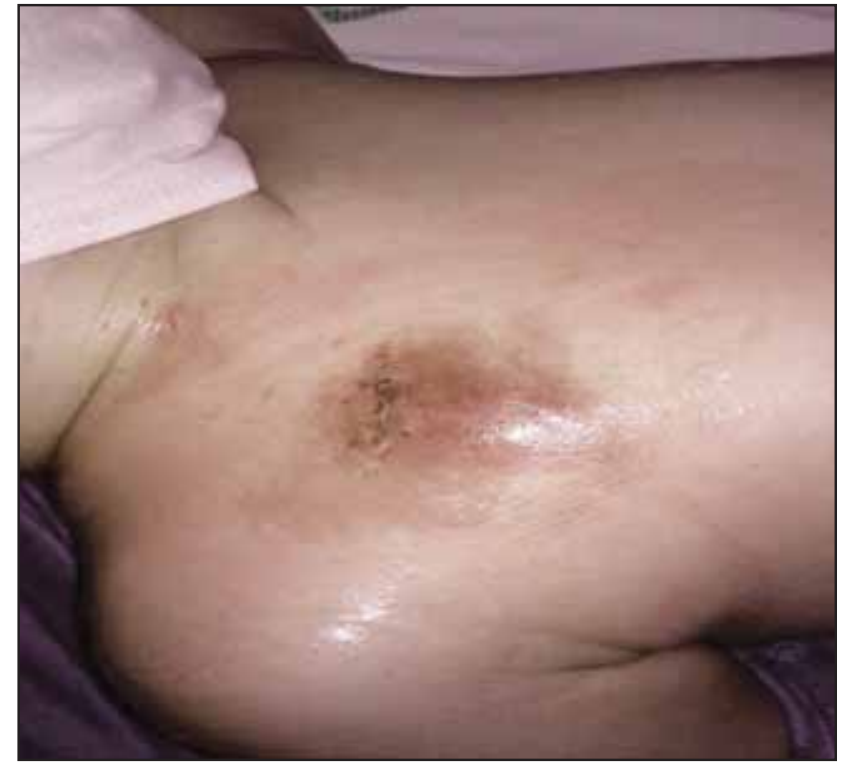

FIGURA 10. Plagă suprainfectată deasupra CVC prin sistem port la un pacient de 4,5 ani cu LAL pre B risc mediu

La pacientul cu limfom Hodgkin în perioada de aplazie s-a reactivat Zona Zoster, motiv pentru care l-am izolat, iar peste o zi l-am şi externat (fiind sursă de infecție letală pentru restul pacienților internați), după ce am instituit tratament cu Aciclovir $80 \mathrm{mg} / \mathrm{kgc}$ timp de o lună. (13)

\section{DISCUȚII}

Distribuția patologiei pe grupe de vârstă în cazuistica noastră a respectat datele din literatura de specialitate care spune, că LAL este mai frecventă la copiii cu vârsta de 3-8 ani, iar limfoamele şi tumorile solide afectează vârsta pubertară-adolescentă. Patologia infecțioasă nu a depins de boala de bază.

Citopeniile erau corectate cu masă eritrocitară, masă trombocitară şi FSCG subcutan. În cazul leziunilor bucale (mucozite) tratamentul local antiseptic şi antialgic, antibioterapia şi medicaţia antifungică intravenoasă, respectiv FSCG pentru creşterea numărului leucocitelor au ajutat pacientul în această perioadă.

Semnele clinice în pneumonia bacteriană sunt tuse, febră, dispnee. Tratamentul constă din antibioterapie asociată (CG2-3, Meropenem, tratament antistafilococic) şi suport imunologic prin imunoglobuline intravenoase. Aspergiloza pulmonară (tuse seacă iritativă, subfebrilitate/febră, dispnee, hemoptizie) este greu de tratat cu o prognoză sumbră în ciuda medicației asociate (Caspofungin, Voriconazol). $(9,10)$ Pentru prevenirea infectiei cu Pneumocystis carinii toți pacientii cu tratament intens citostatic 
beneficiază de profilaxie cu Trimetoprim/Sulfamethoxazol 3 ani, 3 zile/săptămână (V, S, D).

O patologie infecțioasă extrem de temută este enterita necrozantă-tiflita, respectiv abcesul perianal putând duce la sepsis în timp scurt. Simptomatologia caracteristică constă din durere intensă abdominală, diaree şi durere în poziţie şezândă sau la defecație. Tratamentul antibiotic asociat de spectru larg administrat 2 săptămâni şi imunoglobulinele intravenoase rezolvă infecțiile. (11)

Tratamentul infecțiilor cutanate constă din spălarea zilnică a regiunilor infectate cu soluție de Cloramină, deschiderea şi evacuarea colecțiilor purulente, antibioterapie sistemică care vizează Stafilococul ca şi germen şi imunoglobuline intravenoase. (12)

Infecțiile virale sunt extrem de periculoase pe organismul imunodeprimat, toți pacienții care sunt contacți sau chiar dezvoltă simptome de boală infecto-contagiosă sunt izolați, iar în cazul varicelei/ herpes zoster instituim tratament cu Aciclovir 80 $\mathrm{mg} / \mathrm{kgc}$ timp de o lună. (13)

$\mathrm{Cu}$ excepția pacientului de 12 ani cu LAL cr. Ph pozitiv şi a pacientei de 4,5 ani cu LAM la care s-au asociat patologiile respiratorii, enterale şi cutanate, la restul pacienților am observat o predilecție pentru diferitele patologii, suspicionând că are legătură cu statusul immunologic al acestora şi îndemnându-ne să păşim la un alt nivel în viitor pentru studierea background-ului imunologic al pacienților hemato-oncologici. (14)

\section{CONCLUZII}

Momentul diagnosticului de cancer în stadiile avansate de boală scade şansa de vindecare a pacienților. Tratamentele citostatice cauzează aplazii severe, care sunt mai pronunțate la copiii cu hemopatii maligne, unde măduva este afectată, decât la cei cu tumori solide, unde măduva osoasă nu este infiltrată cu blaşti, iar aplaziile sunt mai scurte şi mai uşor de corectat. Majoritatea manifestărilor clinice apărute în perioada aplaziilor sunt de origine infecțioasă şi depind şi de imunitatea copilului şi de complianța mamei care ajuta la respectarea/menținerea regulilor igieno-dietetice impuse. Fără tratamentul suportiv nu este posibilă supraviețuirea pe parcursul tratamentului citostatic. Fiecare episod de aplazie poate fi considerat pericol real pentru viaţa pacientului, iar exitusul poate apărea prin complicațiile septice sau sângerare extremă.

Aplazia medulară postcitostatică a avut durata şi severitatea diferită, în funcție de tipul de cancer. Durata, severitatea complicaţiilor clinice şi rezistenţa la tratament au fost severe în LAL şi leucemia mieloblastică. Complicațiile infecțioase au evoluat cu nuanțe individualizate generate probabil de particularităţile imunologice.

\section{Mulțumiri}

Dorim să transmitem recunoştința noastră Universităţii de Medicină şi Farmacie Târgu-Mureş, dar şi personalului Clinicii noastre, atât asistentelor, cât şi colegilor medici. 